\title{
The Case for Digitizing Fiction with History
}

\author{
by Nancy Patterson Shires
}
s there a case for digitizing fiction in support of history? Some librarians might be surprised to find that there is, and others might be surprised at the actual reasons or the perhaps the strength of the reasons.

In September 2001, J. Y. Joyner Library at East Carolina University opened to the public the Eastern Carolina Digital History Exhibits $<$ http://www.lib.ecu.edu/exhibits>, which initially included:

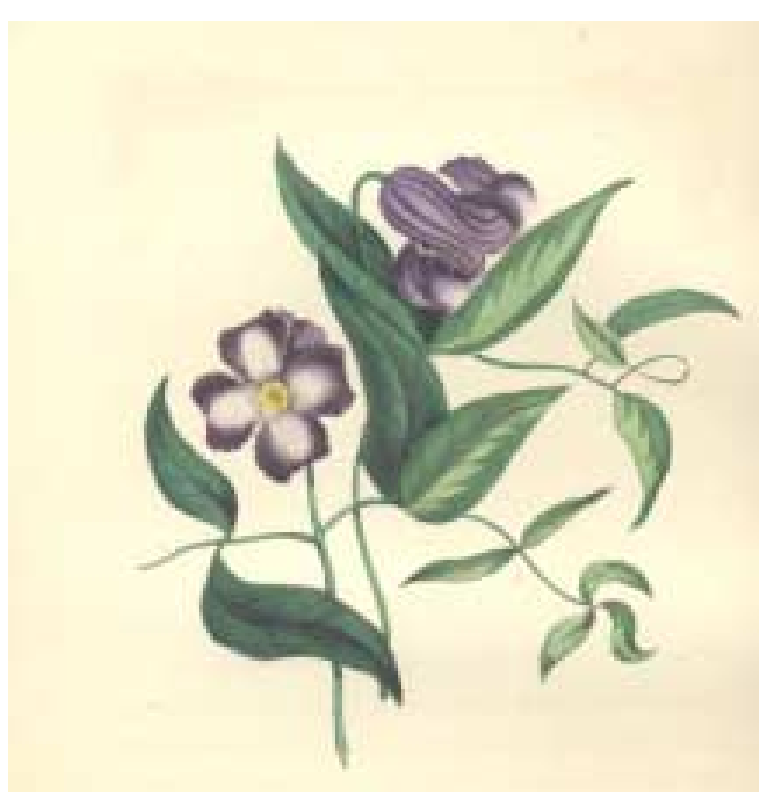

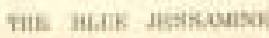

Beautiful plates of native wildflowers adorn the first children's book with a North Carolina setting (New Bern), Mary Ann Bryan Mason's A Wreath from the Woods of Carolina. the tobacco industry in Pitt County; the steamboat industry that was active in the rivers and sounds of the eastern part of the state; the life and activities of John Lawson, an early eighteenth-century explorer of North Carolina; and the beginnings of East Carolina University. The aspects of history chosen are particularly important to the eastern region of the state, which the university and its library serve.

About the same time that the digital history exhibits went public, the North Carolina Collection at Joyner Library, which is responsible for one of the exhibits, received a remarkable collection of fiction set wholly or partially in North Carolina. The fiction includes some rare items, a number of historical novels, and novels written during important historical periods, such as the Civil War, or set locally, such as in New Bern or Kinston. ${ }^{1}$ The question naturally arose: could the fiction be used to support the digital historical exhibits also benefit those interested in eastern North Carolina history?

This question led to a search of the Internet to see if fiction is being included in digital history Web sites. I found that most of these Web sites do not include fiction - a notable exception being the University of North Carolina at Chapel Hill's Documenting the American South. ${ }^{2}$ However, considering the realities of digital history projects, it is perhaps amazing that fiction is included at all. First of all, these projects are undertaken largely by academic libraries and state archives, whose first concern is to provide primary source material such as letters and diaries. Most digital history Web sites are relatively new and just developing. The technical difficulties, copyright problems, time, effort, staff, and costs of
\end{abstract}


the projects are high, with the result that relatively few sources can be digitized and selection of sources tends to be rigorous. Finally, and not to be ignored, are widely held cultural biases affecting fiction, or what Joseph Gold calls Frock Coat (fiction is the lofty privilege of a small class of well-to-do dilettantes); Waste of Time (fiction is frivolous, impractical, untrue, non-essential, and not productive of money); and Criticizing to Death (fiction is objects of art approachable only by a few, self-appointed experts). ${ }^{3}$

In spite of the obstacles, fiction does appear on some digital history Web sites and, as Erich J. Kesse, director of the Digital Library Center at the University of Florida <http://web.uflib.ufl.edu/digital/ops>, says: "I have faith that as digital history libraries mature, particularly in the South with its long traditions of oral history and fiction, we'll include more fictional resources." ${ }^{4}$ For the Florida Heritage project, he anticipates converting the works of Marjorie Kinnan Rawlings and Zora Neal Hurston, among others.

Further research provided some surprising and compelling reasons for keeping fiction in the queue of documents to be digitized, and for those

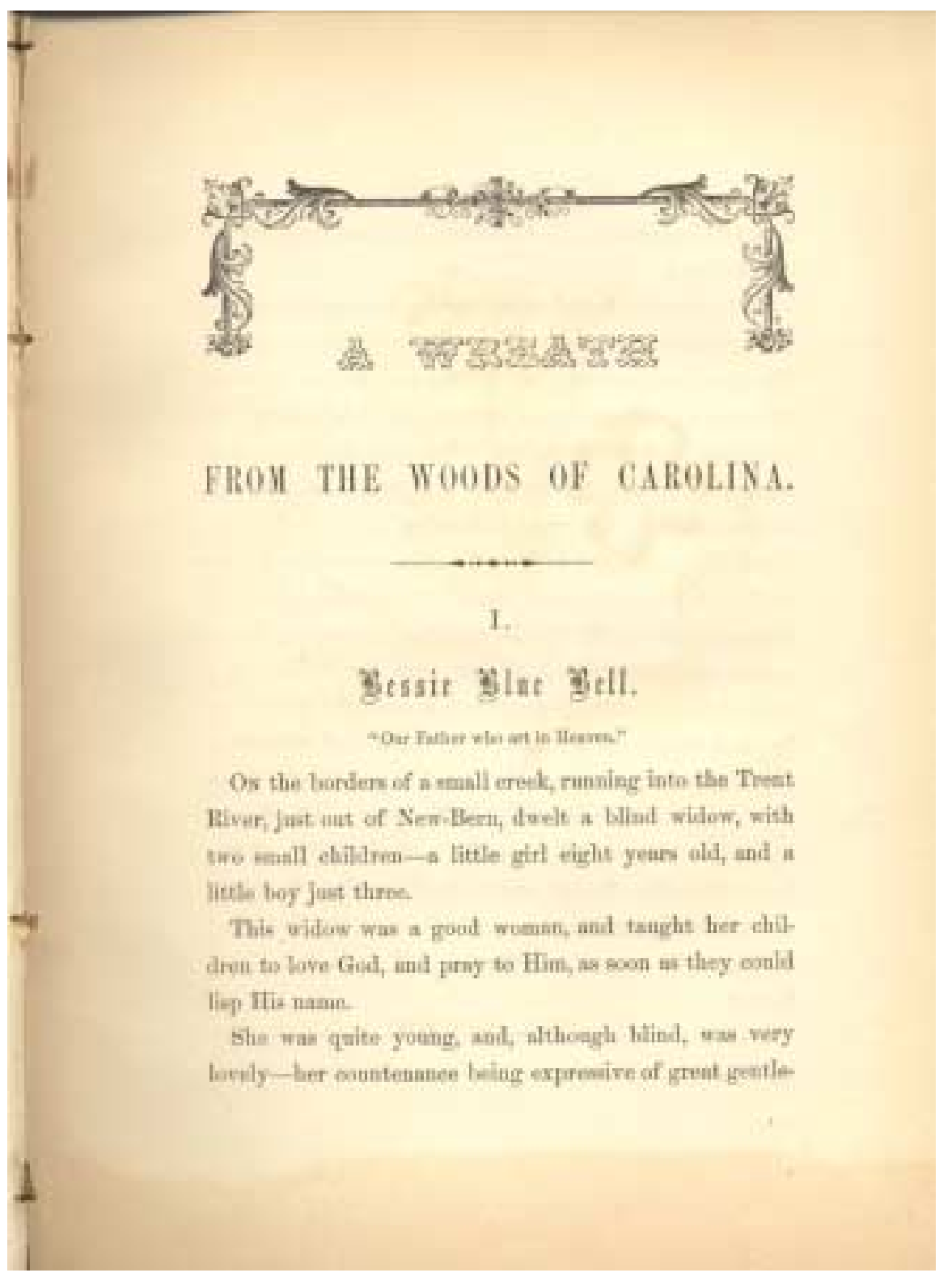

The moralistic tone of Mason's 1859 book is typical of the literature for children at that time. who are considering the inclusion of fiction in a digital history project - or particularly for those who have never even considered the idea - some of these reasons are summarized below.

\section{Support from the Classroom}

Novels, particularly historical ones, are neither new nor out-of-date in the history classroom, simply because they are effective in teaching and learning. The OAH Magazine of History recently devoted a special issue (Winter 1999) to the use of literature in teaching history. One participating teacher, for example, reported using Hawthorne's The House of the Seven Gables and Margaret Fuller's Woman in the Nineteenth Century to add context to American history for secondary and college students. ${ }^{5}$

In other research, a teacher found that "historical fiction is not the most efficient way to teach history ... nor is it the most interesting way ... Historical fiction is, however, the most effective way .... It gives children a background for historical events, allowing them to relive the past, to internalize it, and thereby remember it far better than they remember information from a textbook. It encourages them to consider the causes of historical events and the consequences of those events on human lives." 6 The curriculum lab librarian at Central Connecticut State University found that many students were novices at historical research and had difficulty formulating research questions, but that historical fiction 
could give them both necessary background and an entry into research. ${ }^{7}$

Jay Pecora, who teaches at Satellite Academy in New York City, is quoted online at the History Matters Web site under "Secrets of Great History Teachers": "I want students to walk away from my classes excited by the narrative of history. I also want them to discover their inner resources for handling situations of conflict in their lives ... and understand the actions of people in the past in a visceral way." ${ }^{\prime 8}$

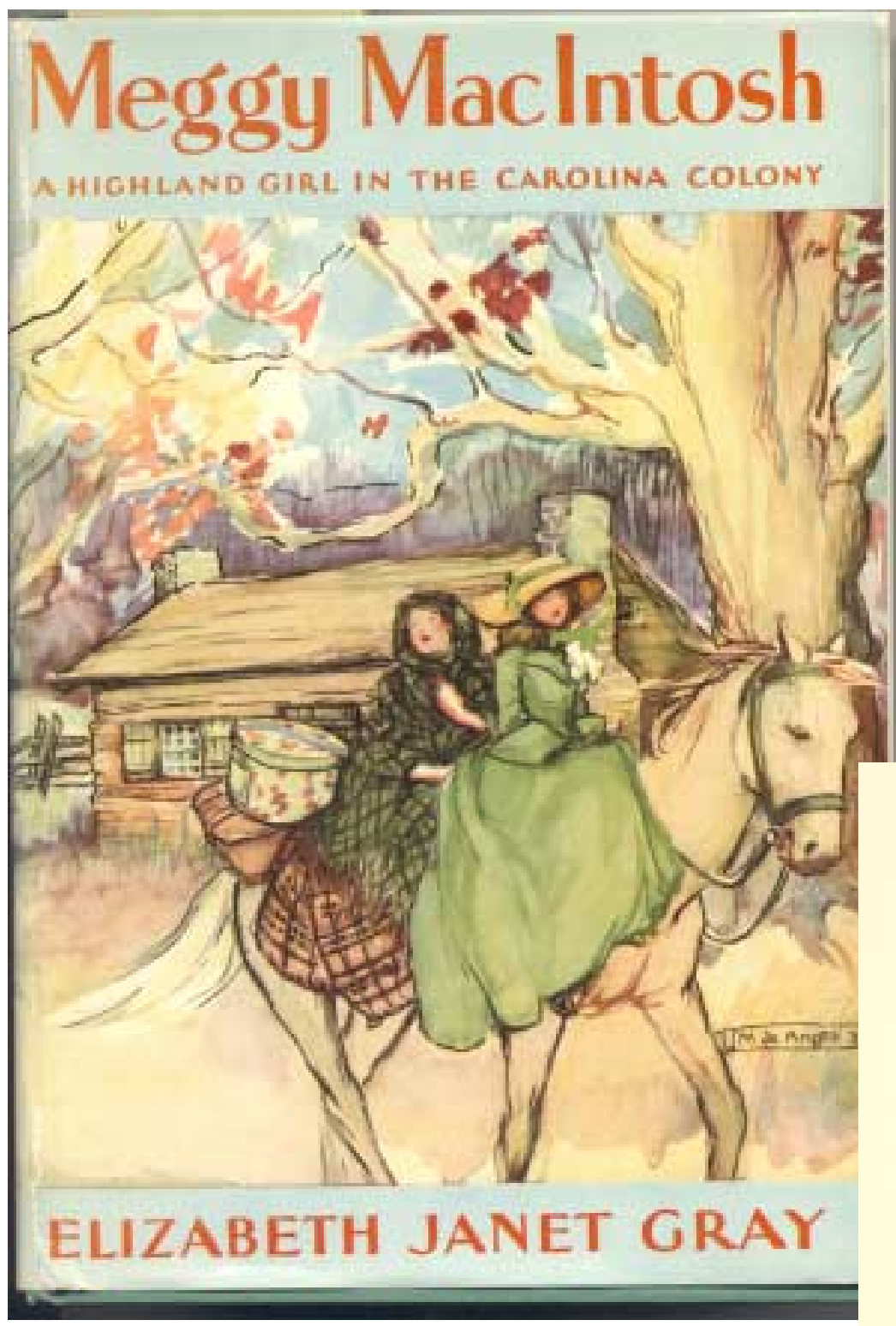

Though listed as a juvenile book, Gray's 1930 novel Meggy Maclntosh is a fine read for adults, too. It established new standards for children's literature, lifting it from its didactic past.

Right: Meggy Maclntosh, a young Scottish girl, sneaks aboard a ship to the Carolina colonies (Wilmington) just before the American Revolution to meet her heroine Flora MacDonald.
Speaking to many students and teachers at the 2002 North Carolina Literary Festival, journalist Susan Byrum Rountree related her own experience. She took every North Carolina history course offered at the University of North Carolina at Chapel Hill but did not develop any real enthusiasm or appreciation for history until she moved to Georgia and had to read that state's "official history," Margaret Mitchell's novel Gone with the Wind. Consequently, she became a historian and recently published The Nags Headers. ${ }^{9}$

\section{Support from Social Research}

In modern society, research indicates that the burden of storytelling has shifted to written fiction. Moreover, written fiction is the best and one of the very few places where story can function in modern society.

Social historians have studied the importance of story in preserving human cultures and

174

\section{MEGGY MACINTOSH}

funds in hand to help them, and keep them loyal. And I doot it will be masy a king day before I can wring teimburivement oot o' the government. His Excellency saw to it that the ship did not pass the Cruiser without all the men taking the Oath of Allegiance. They'll get to Cross Creek in time tae join the Highland regiment."

"Governor Martin made them take the Oath of Allegiance before they landed?" repeated Mesry. "But they have not seen this country yet. How can they tell how they will feel towand it? They may not wish to fight against it after they have been here for a time"

"Aye, that is exactly the contingency that His Excellency is endeavoring to fotestall," admitted Flara MacDonald's son-in-law composedly.

"Bat it is not fairl"

"Perhapu not, perhaps not. It's war, lask, and besides, 'tis best for them in the long run. There's nought to be gained by fighting againat the King. Look at Culloden, and the fate that they had who fought againat the King there, $"$

Megry was silent. She was thinking of that terrible oath, and of the men who had been compelled to swear. Exhausted by the long voyage across the oceun they must have been, and braced for the difficult tank of making a home and a living for their families in this ntranghe new land where most folk knew not their Garlie tongue. How those cutting plirases must secan to have been coined for them ... "May 1 be killed in hattie as a 
have documented the fall of the oral tradition and the rise of the written one, with all the resulting changes in social classes, power structures, and lines and means of communication. The rise of the modern media and "the information age" in relation to human communities has also been studied. Significant findings are:

- The modern media, including television, radio, newspapers, and magazines, have not taken over the responsibility for story and, in fact, more often than not, discourage it. ${ }^{10}$

- Fiction engages and connects, provides complexity, humanizes, and makes whole or completes. Story allows individuals to "live" meaningful experiences outside their limited time periods and geographical locations and to know other people intimately and connect with them. ${ }^{11}$ These qualities are particularly important in modern society, where the common characteristics are alienation or detachment (e.g., bored adolescents who find school irrelevant); simplification or oversimplification (e.g., dumbing down); dehumanization (e.g., how violence is used to attract

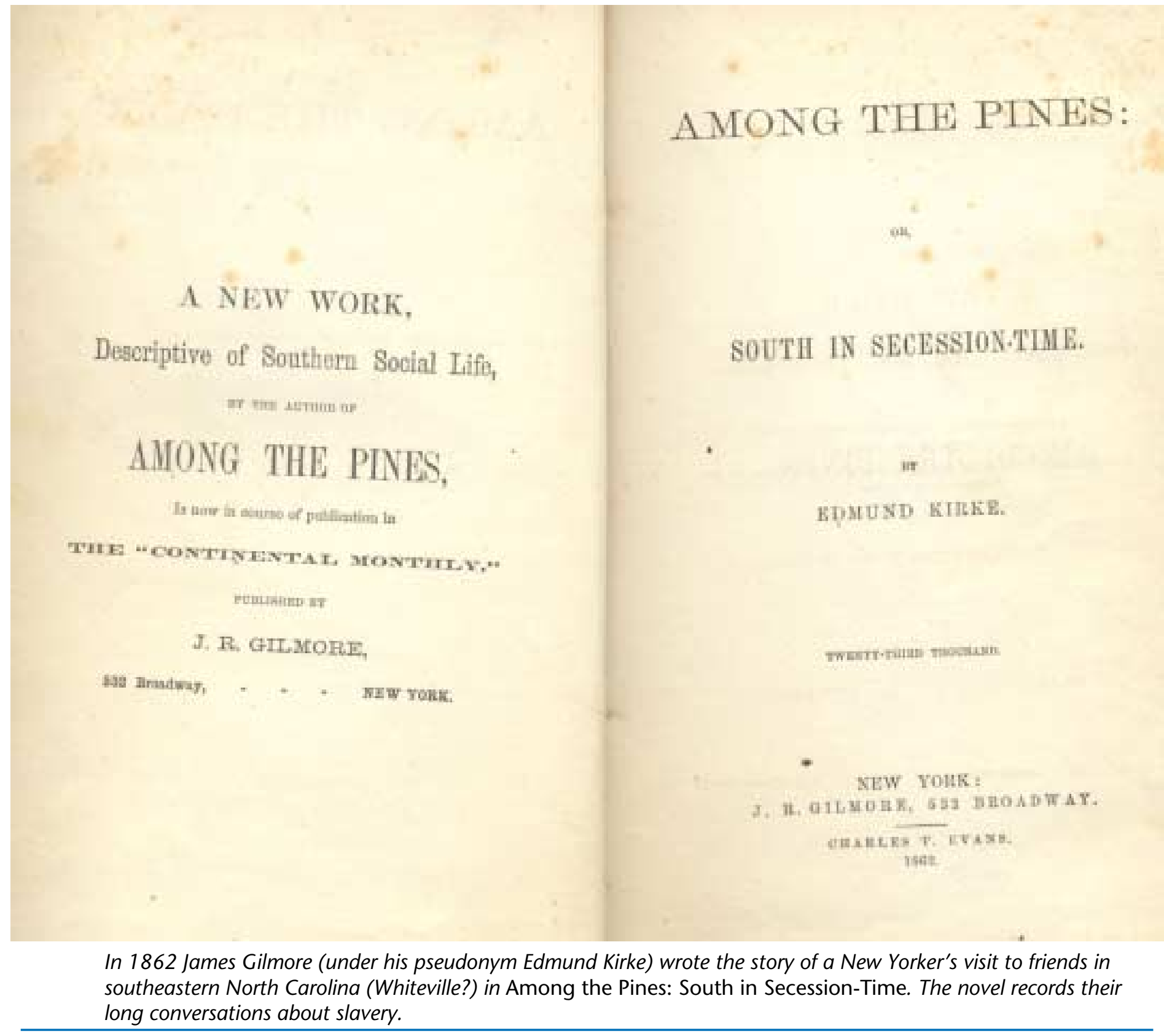


audiences); and incompleteness (e.g., shallowness of most news stories). Neil Postman writes: "As no other medium before or since, the book promotes a sense of a coherent and usable past."12

\section{Support from Brain Research, Neurolinguistics, Psychology, and Related Areas}

Evidence from various scientific fields is revealing that the human brain has evolved in a way that prefers or relies on the structure and process of story. In his new work The Story Species: Our Life-Literature Connection, Joseph Gold asserts that human brains will organize data into stories no matter what they are constructing. Literature (i.e., fiction or story) is "built upon a brain process for manag-

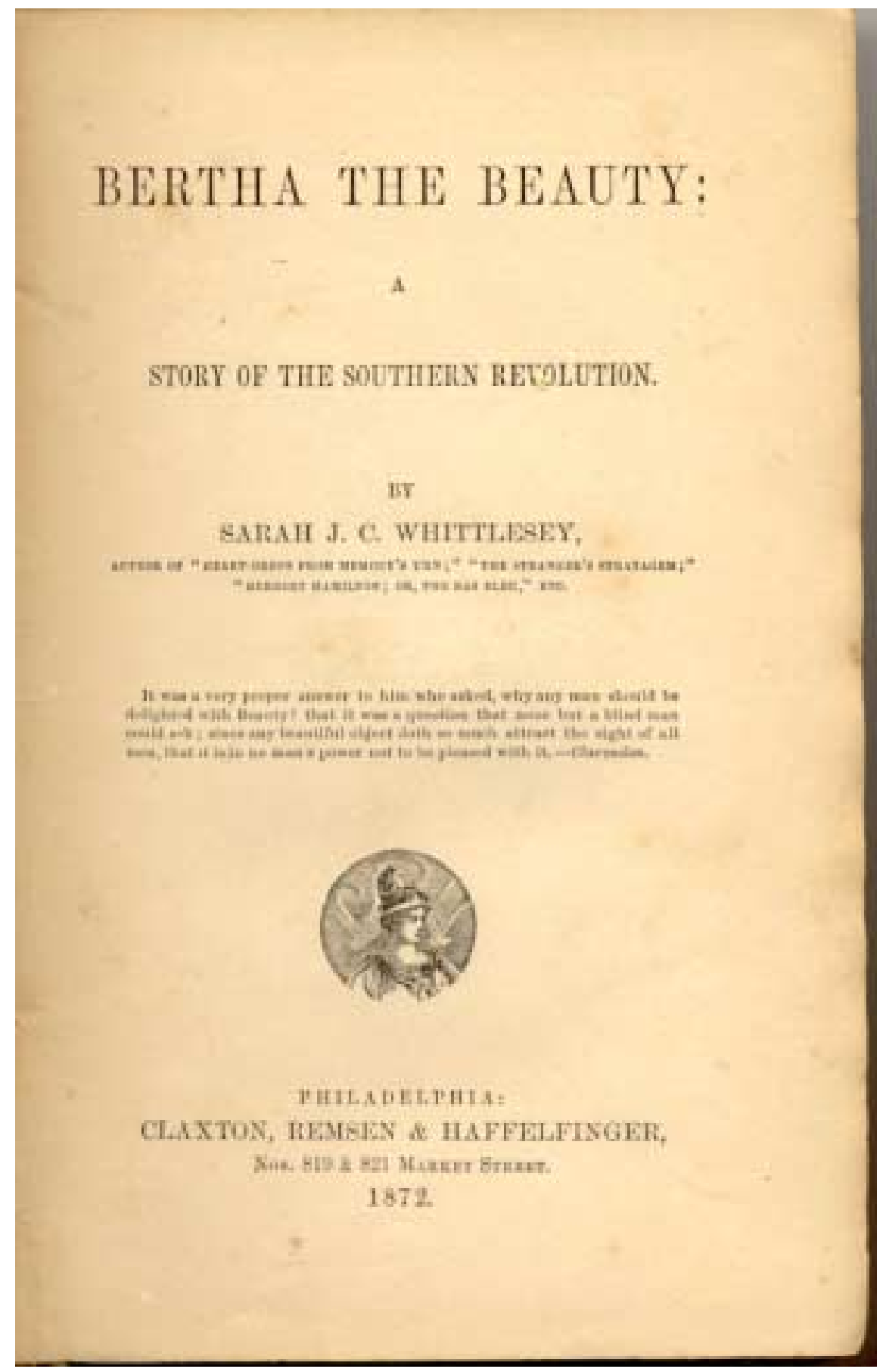

Williamston author Sarah J. C. Whittlesey's 1872 novel Bertha the Beauty is typical of the sentimental literature published after the Civil War (1872). ing and transmitting information" and is "an evolved brain strategy that uses story sequencing as a management tool for organizing vast amounts of information."13

Story may indeed be crucial to managing and developing as humans must in order to survive and cope with the world. "Only Literature can make life intelligible, unified, organized," Gold writes. ${ }^{14}$

The complex text of fiction activates or calls upon many areas and processes of the brain, including the five senses. There is no comparable source of such complexity. A very basic description of the process is that the left brain decodes, and the right brain supplies the three-dimensional images, smells, emotions, and ambient textures. ${ }^{15}$ Thus, the reader not only learns a numerical date and the name of a geographical place, but also feels the hot, dry wind blowing in the face of the droughtstricken farmer and makes the experience his or her own. In this way, history is remembered better.

One way that fiction accomplishes its unique mission is that it engages emotion. Emotion, far from being negligible or dangerous, as it is often considered in Western thought, is essential to memory. The neurologist Antonio Damasio writes: "Feelings, along with the emotions they come from, are not a luxury."16 Gold adds: "Emotions are thus a vast extension of thinking ability."17

From the perspective of psychology, fiction has been found to help individuals form and constantly revise identity, a process necessary for growth and maturation. Also, when emotion is joined with thought, the person ad- 
vances toward wholeness.

As for television, brain research shows that during the barrage of advertising messages or other bits of information or entertainment, the neocortex is largely inactive and neural networks are slowed down in change and growth. ${ }^{18}$

\section{Conclusions}

Including relevant fiction along with digitized history helps the reader to deal effectively with the various letters, photos, and census records or the individual bits and pieces of history revealed. It is an organizer and a model and helps the reader form the fragments of digital history into

William D. Herrington (Pactolus, Pitt County) served as a Confederate soldier and wrote these two novelettes in 1864-65. Though not considered "good" literature, the novelettes were snapped up by the book-hungry public of the time and, for later readers, they describe the camp and social life of Civil War soldiers and less well-known engagements in the Kinston area.

\section{FACSIMILE EDITION}

\section{The Captain's Bride \\ A Tale of the War}

and

\section{The Deserter's Daughter}

\author{
by
}

William D. Herrington

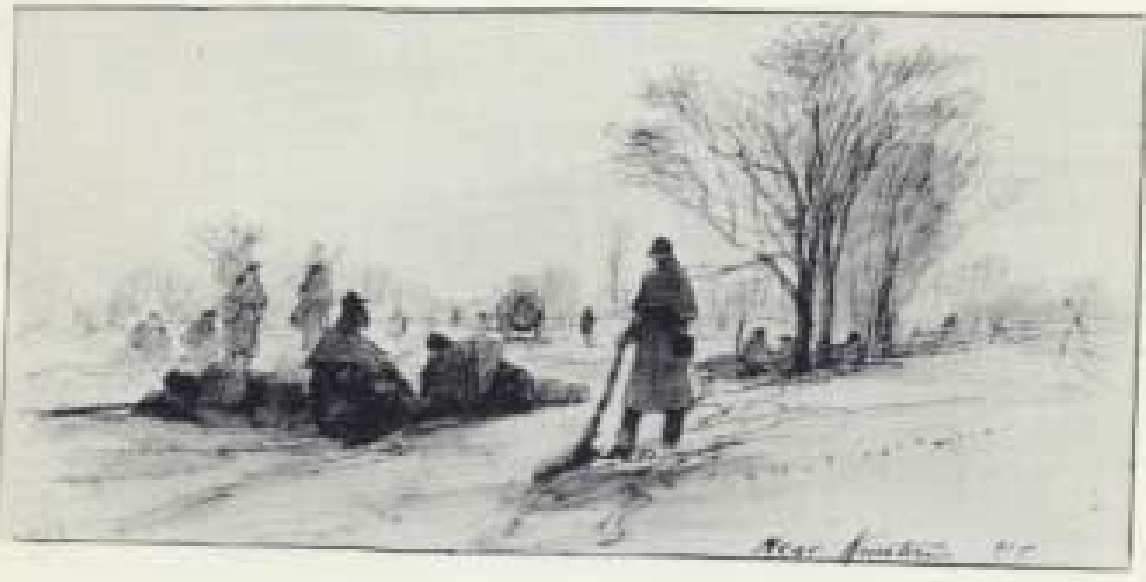

EDITED BY W. KEATS SPARROW 
a meaningful whole.

A further implication for librarians arises: how much more effective could a digital history site be if the whole were envisioned as a narrative, the story of a particular thing, with all the digitized documents contributing chapters, subplots, characters, and such? The undergirding structure of story can bring the parts together into a meaningful whole, something to be kept in mind as priorities are established and resources selected and as documents are gathered into sections and cross-links provided.

Edward Ayers at the University of Virginia suggests, "Could it be that digital archives might move us toward more complex, more literary, forms of narrative?" He foresees that digital archives will proliferate and that historians can be catalysts in the creation "of a more literary kind of history."19

Adjustments may have to be made. If a novel is quite long, for example, or if it is readily available in many libraries, perhaps only a chapter or significant passages can or should be digitized. Still, such fictional selections could be valuable and also would lead Web site readers to the full original work of fiction.

In conclusion, for a variety of reasons - educational, social, psychological, biological - fiction is important in the study of history. Not only can novels and stories be valuable additions to digital history Web sites, but also narrative structure itself can enhance their usefulness.

\section{References}

1 The fiction titles discussed here are included in the Snow L. and B. W. C. Roberts Collection, donated in May 2001, and called by appraiser Joseph Natale of Chapel Hill, "one of the largest, if not the largest such collection ever formed by an individual," in his appraisal letter of April 21, 2001.

2 This site is available at $<\mathrm{http}$ //docsouth.unc.edu>. Fiction is listed clearly as one of the categories.

3 Joseph Gold, The Story Species: Our Life-Literature Connection (Allston, MA: Fitzhenry \& Whiteside, 2002), 222-33.

4 Erich J. Kesse, e-mail, June 4, 2002.

5 Elizabeth Fay and Wayne Hatmaker, "Lived History: A Multimedia Approach," OAH Magazine of History 13 (Winter 1999): 14-16.

6 Kathy Nawrot, "Making Connections with Historical Fiction," The Clearing House 69 (July/Aug. 1996), 343-45.

7 Frances A. Nadeau, "Fiction as a Springboard to U. S. History Research Projects," The Social Studies 85 (Sept.-Oct. 1994): 222-24.

8 Jay Pecora, interview, available at $<$ http://historymatters.gmu.edu/d/ $6479>$.

9 Susan Byrum Rountree, North Carolina Literary Festival, Chapel Hill, April 6, 2002. Author of Nags Headers (Winston-Salem: John Blair, 2001).

10 See, for example, Chapter 10: "Media Madness," in Gold, Story Species, 166-81.

11 Terrence W. Deacon. The Symbolic Species: The Co-Evolution of Language and the Brain (New York: Norton, 1997), 430.

12 Neil Postman, quoted in Gold, Story Species, 215.

13 Gold, Story Species, xxiv, 17.

14 Ibid., 46.

15 Ibid., 113.

16 Antonio Damasio, Descartes' Error (New York: Grosset/Putnam, 1994), xv.

17 Gold, Story Species, 77

18 Ibid., 159.

19 Edward L. Ayers, "The Pasts and Future of Digital History," available at $<$ http://www.vcdh.virginia.edu/PastsFutures.html $>$. 